\title{
Pulmonary artery sarcoma mimicking pulmonary embolism
}

\author{
Po-Wei Chen, ${ }^{1,2}$ Ping-Yen Liu ${ }^{1,2}$
}

${ }^{1}$ Division of Cardiology, Department of Internal Medicine, National Cheng Kung University Hospital, College of Medicine, National Cheng Kung University, Tainan, Taiwan ${ }^{2}$ Institute of Clinical Medicine, College of Medicine, National Cheng Kung University, Tainan, Taiwan

\section{Correspondence to}

Dr Po-Wei Chen,

huntershobow@gmail.com

Accepted 20 August 2018

\section{DESCRIPTION}

A 62-year-old woman with diabetes presented with progressive exertional dyspnoea, chest pain and palpitation for several months. She had no history of leg oedema, fever, bodyweight change and general weakness. Therefore, she received associated exams at cardiovascular outpatient department. Transthoracic echocardiogram showed right atrium and ventricle dilatation with severe pulmonary hypertension. Besides, a thrombus-like mobile mass was noted at right ventricle and pulmonary artery (figure 1, video 1 ). Pulmonary embolism, as one of the life-threatening conditions, was our tentative diagnosis, and she was transferred to the emergency department. Chest CT showed multifocal filling defects at right ventricle, main pulmonary artery trunk and bilateral pulmonary arteries with several lung nodules (figure 2). Primary tumour or metastasis

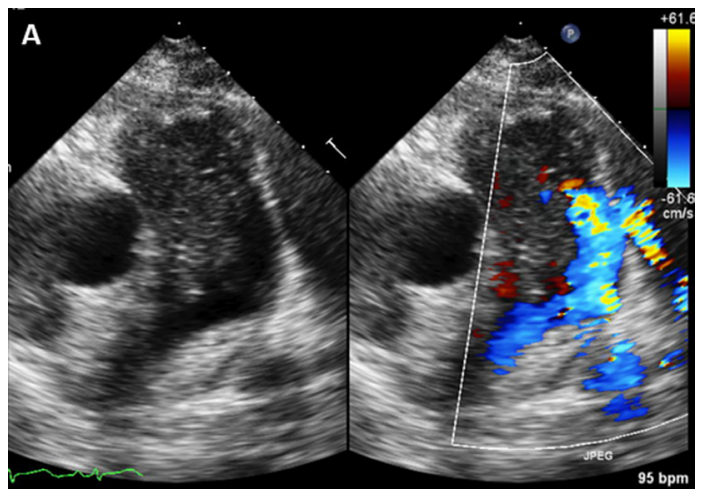

Figure 1 Transthoracic echocardiogram showing a thrombus-like mobile mass at the main trunk of pulmonary artery.

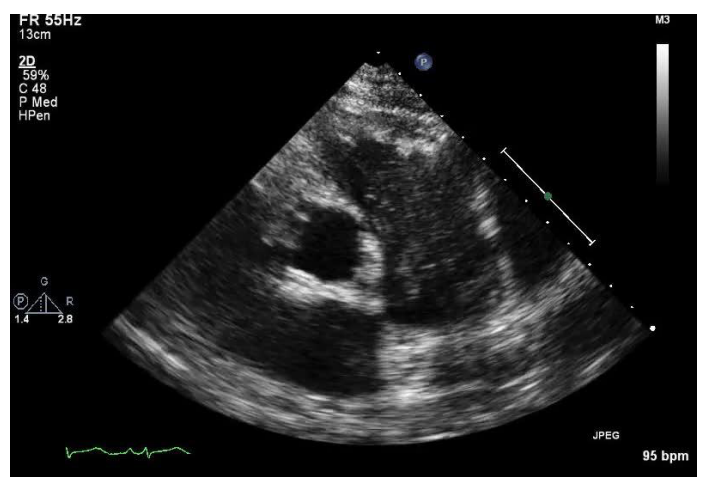

Video 1 Modified parasternal short-axis view at aortic valve level by transthoracic echocardiogram showing a heterogeneous mobile mass at the main trunk of pulmonary artery.

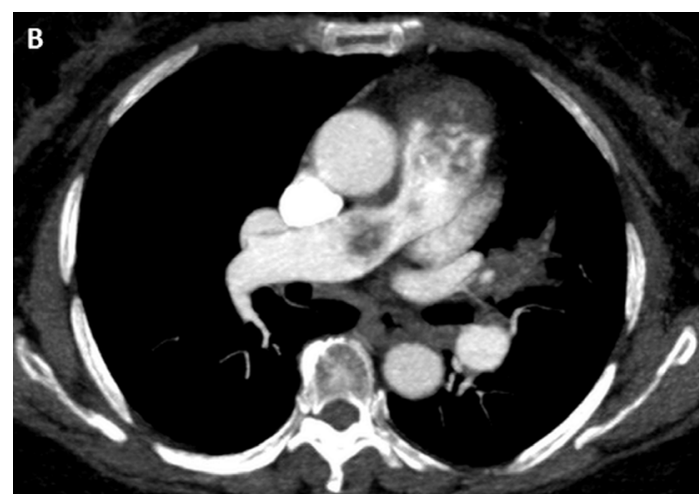

Figure 2 Chest CT showing multifocal filling defects at the main trunk of pulmonary artery and bilateral pulmonary arteries with several lung nodules.

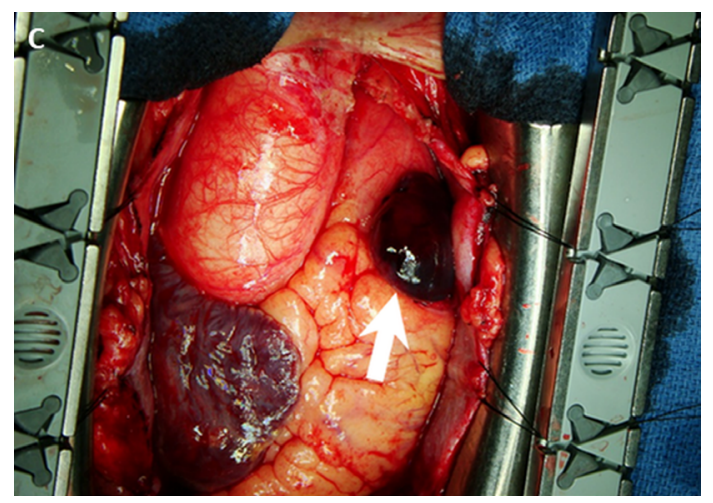

Figure 3 One well-defined tumour was located at the main trunk of pulmonary artery.

was our final impression by image study. Finally, the patient underwent surgery, which confirmed the mass to be pulmonary artery intimal sarcoma, not a large thrombus (figure 3 , arrow).

Learning points

- The diagnosis of pulmonary artery sarcoma should be considered in patients who present with pulmonary embolism, especially poor response to anticoagulant therapy.

- Thrombus and mass are difficult to differentiate, even with transthoracic echocardiogram and chest CT.

- Team work should be organised for final diagnosis, involving echo specialist, cardiovascular surgeon and radiologist.

Contributors Chen PW was the physician of the patient, also drafted the manuscript and designed the figures. Liu PY supervised 
the findings of this work. Both authors discussed the results and contributed to the final manuscript.

Funding The authors have not declared a specific grant for this research from any funding agency in the public, commercial or not-for-profit sectors.
Competing interests None declared.

Patient consent Next of kin consent obtained.

Provenance and peer review Not commissioned; externally peer reviewed.

Copyright 2018 BMJ Publishing Group. All rights reserved. For permission to reuse any of this content visit http://group.bmj.com/group/rights-licensing/permissions.

BMJ Case Report Fellows may re-use this article for personal use and teaching without any further permission.

Become a Fellow of BMJ Case Reports today and you can:

- Submit as many cases as you like

- Enjoy fast sympathetic peer review and rapid publication of accepted articles

- Access all the published articles

- Re-use any of the published material for personal use and teaching without further permission

For information on Institutional Fellowships contact consortiasales@bmjgroup.com

Visit casereports.bmj.com for more articles like this and to become a Fellow 